\title{
MODEL PERENCANAAN AGREGAT UNTUK SISTEM PRODUKSI DUA TAHAP PADA INDUSTRI PANGAN DENGAN BAHAN PERISHABLE
}

\section{AN AGGREGATE PLANNING MODEL FOR TWO-STAGE PRODUCTION SYSTEMS IN THE FOOD INDUSTRY WITH PERISHABLE GOODS}

\author{
Afifah Nur Arfiana), Taufik Djatna ${ }^{2)}$, Machfud²), Indah Yuliasih ${ }^{2)}$ \\ ${ }^{1)}$ Program Studi Pascasarjana Teknik Industri Pertanian, Institut Pertanian Bogor \\ ${ }^{2)}$ Departemen Teknologi Industri Pertanian, Fakultas Teknologi Pertanian, Institut Pertanian Bogor, \\ J1. Raya Dramaga, Babakan, Dramaga, Bogor 16680, Indonesia \\ E-mail: arfianaafifah@apps.ipb.ac.id
}

Makalah: Diterima 26 November 2020; Diperbaiki 26 Maret 2021; Disetujui 15 April 2021

\section{ABSTRACT}

Aggregate planning is one of the most important activities of operation management for a competitive supply chain. Aggregate planning balances supply and demand during the planning time horizon. Aggregate planning in a food industry with perishable goods characteristics is a common problem. Mostly, studies on aggregate planning were only concerned with single product and single-phase production process. This paper proposed a two-stage aggregate planning model that can be applied in the food industry with perishable goods characteristics, multi-products, and multi-periods. The two stages of the production process consisted of processing raw materials into intermediate products and processing intermediate products into final products by implementing postponement or intermediate product storage. Processing of raw materials into intermediate products was expected to solve the problem of material deterioration rate, because storing intermediate products was more durable than storing raw materials. The proposed aggregate planning model used a mathematical model approach and was solved by using goal programming. Based on the results of model verification using hypothetical data and sensitivity analysis, the aggregate planning model obtained the feasible decision variable value and could be applied to the food industry which implements a two-stage production system.

Keywords: aggregate planning, two-stage production system, perishable goods, modelling

\section{ABSTRAK}

Perencanaan agregat adalah salah satu bagian terpenting dari manajemen operasi dalam rantai pasok yang kompetitif. Perencanaan agregat berkaitan dengan kesesuaian jumlah pasokan (supply) dengan permintaan (demand) selama periode perencanaan. Perencanaan agregat pada suatu industri pangan dengan karakteristik bahan perishable menjadi suatu permasalahan yang biasa terjadi. Umumnya, kajian mengenai perencanaan agregat yang diusulkan hanya berkaitan dengan single product dan single-phase production process. Paper ini mengusulkan suatu model perencanaan agregat dua tahap yang dapat diterapkan pada industri pangan dengan karakteristik bahan perishable, multi-products, dan multi-periods. Dua tahap proses produksi terdiri atas pengolahan bahan baku menjadi produk antara dan pengolahan produk antara menjadi produk akhir dengan menerapkan penundaan atau penyimpanan produk antara. Pengolahan bahan baku menjadi bahan antara diharapkan dapat mengatasi permasalahan laju deteriorasi bahan karena menyimpan produk antara dapat dilakukan lebih lama atau lebih awet dibandingkan menyimpan bahan mentah. Model perencanaan agregat tersebut menggunakan pendekatan model matematika dan diselesaikan dengan teknik goal programming. Berdasarkan hasil verifikasi model menggunakan data hipotetik dan analisis sensitivitas, model perencanaan agregat dapat menghasilkan nilai variabel keputusan yang layak dan dapat diterapkan pada industri pangan yang menerapkan sistem produksi dua tahap.

Kata kunci: perencanaan agregat, sistem produksi dua tahap, bahan perishable, pemodelan

\section{PENDAHULUAN}

Perencanaan agregat merupakan salah satu bagian terpenting dari manajemen operasi (Djordjevic et al., 2019), dan memiliki dampak yang signifikan terhadap kinerja rantai pasokan yang kompetitif (Chopra dan Meindl, 2016). Perencanaan agregat menyeimbangkan jumlah pasokan (supply) dengan permintaan (demand). Menurut Mehdizadeh et al. (2018), tujuan perencanaan agregat adalah untuk menetapkan tingkat output secara keseluruhan untuk menghadapi permintaan yang berfluktuasi atau tidak menentu serta untuk menyediakan pasokan.
Perencanaan agregat menghasilkan kuantitas produksi dan waktu produksi barang yang optimal serta bahan baku dan sumber daya yang ada, untuk meminimalkan total biaya operasional organisasi. Merujuk pada Heizer dan Render (2004), perencanaan agregat umumnya merupakan perencanaan kapasitas jangka menengah selama jangka waktu 3-18 bulan.

Cabang riset operasi yang umum digunakan dalam pendekatan model matematika untuk perencanaan agregat antara lain: linear programming, goal programming, integer programming, dan dynamic programming (Al-E-Hashem et al., 2011).

*Penulis Korespondensi 
Dalam prakteknya, perencanaan agregat umumnya memiliki tujuan saling bertentangan dengan penggunaan sumber daya yang dipertimbangkan (Baykasoglu dan Gocken, 2010) dan dinilai dari berbagai perspektif dan ukuran kinerja (Broz et al., 2019). Dengan demikian, pendekatan multi-tujuan lebih tepat daripada tujuan tunggal, sehingga metode goal programming (GP) memadai untuk menyelesaikan berbagai tujuan berbeda dan sering berlawanan dipecahkan dan dicapai secara bersamaan. Selain itu, GP dapat menangani lingkungan yang impresisi dalam perencanaan agregat (Mezghani et al., 2012), dan mampu mengatasi variansi yang dinamis (Huang et al., 2017).

Beberapa penelitian mengenai agregat planning dengan pendekatan GP diuraikan di bawah ini. Rad dan Shirouyehzad (2014) mengusulkan model perencanaan agregat pada suatu industri ubin dengan mempertimbangkan tiga tujuan perusahaan yang harus dipenuhi dan diselesaikan menggunakan goal programming. Da Silva dan Marins (2014), mengusulkan model aggregat planning untuk mengatasi permasalahan yang sangat komplek dan ketidakpastian pada suatu pabrik gula dengan produk berupa gula, etanol, dan molasses menggunakan fuzzy goal programming.

Masalah umum industri pangan adalah sifat perishable bahan, sehingga waktu penyimpanan bahan mentah menjadi terbatas dan berisiko terhadap kekurangan pasokan bahan baku (Shin et al., 2019). Namun, dalam kasus sifat bahan yang perishable, produksi berlebih juga tidak diperkenankan. Selain itu, umumnya model perencanaan agregat berkaitan dengan single product dan single phase production system yang hal tersebut tidak selalu relevan dengan sistem produksi di dunia nyata (Ramezanian et al., 2012). Leung dan Ng (2007) mengusulkan model perencanaan agregat dengan penundaan produksi menjadi dua tahap untuk menangani sifat perishable bahan dalam kondisi sumber daya yang terbatas dan fluktuasi permintaan produk. Menurut Akkerman dan Van Donk (2008), proses produksi dapat dibagi menjadi dua tahap, yaitu pengolahan bahan baku menjadi produk antara dan pemrosesan produk jadi. Menurut Pearn et al. (2011), produksi melalui multistage menjadi tantangan dalam kasus nyata industri saat ini, sehingga diusulkan suatu model perencanaan produksi yang mempertimbangkan pemisahan proses menjadi dua tahap, yaitu tahap 1, bahan baku menjadi produk antara; dan tahap 2, produk antara menjadi produk final. Shin et al. (2019) juga mengusulkan model perencanaan produksi untuk produk perishable, yaitu kimchi, dengan pendekatan twophased inventory.

Selain tantangan multi-stage dalam sistem produksi, perencanaan agregat menjadi lebih kompleks pada kasus multi-product dan multiperiode karena umumnya industri pangan tidak jarang memproduksi beberapa jenis produk. Jey et al. (2017) mengembangkan model perencanaan produksi untuk sistem produksi multi-stage yang dibedakan berdasarkan produksi secara manual dan produksi secara otomatis untuk berbagai macam (multiproduct) produk kimia yang bersifat perishable untuk beberapa periode perencanaan (multi-periode).

Tujuan penelitian ini adalah merancang suatu model perencanaan agregat dengan kasus multi-stage, multi-product, dan multi-periode untuk industri pangan dengan sifat bahan perishable. Luaran dari model adalah tingkat produksi dan tingkat inventory pada masing-masing tahap. Dalam model perencanaan agregat yang diusulkan, tujuan yang ingin dicapai di antaranya dapat memenuhi permintaan, menghasilkan biaya produksi minimal, dan tidak melebihi kapasitas waktu kerja yang ditetapkan. Studi ini didasari oleh kasus sistem produksi dua tahap pada industri pengolahan daging yang memiliki permasalahan kapasitas waktu produksi, fluktuasi permintaan, biaya produksi tinggi, dan sifat bahan perishable. Sebelum data pada studi ini diverifikasi ke model yang diusulkan, perlu dilakukan peramalan permintaan sebagai input dasar untuk perencanaan agregat (Gansterer, 2015).

\section{METODE PENELITIAN}

\section{Kerangkan Penelitian}

Langkah-langkah dan kerangka penelitian dapat dilihat pada Gambar 1. Studi ini didasari oleh sistem produksi dua tahap untuk produk pengolahan daging yang terbagi menjadi dua jenis produk sosis: produk 1, berupa sosis ayam; dan produk 2, berupa sosis sapi. Industri pengolahan daging menerapkan sistem produksi 2 tahap yang tidak semua bahan baku daging langsung diproses menjadi produk akhir sosis namun beberapa disimpan dalam bentuk produk antara berupa adonan sosis. Penerapan sistem produksi dua tahap umumnya berkaitan dengan kendala umur simpan bahan dan produk, serta waktu tunggu saat proses produksi. Penerapan sistem produksi 2 tahap dikarenakan penyimpanan produk antara (adonan sosis) memberikan umur simpan yang lebih panjang dibandingkan dengan penyimpanan bahan baku daging dikarenakan sudah bercampur dengan bahan tambahan pangan lainnya, walaupun belum mengalami proses pemasakan. Dalam sistem produksi dua tahap ini, proses produksi terbagi menjadi tiga, yaitu:

- Pengolahan bahan baku menjadi produk akhir secara langsung

- Pengolahan bahan baku menjadi produk antara

- Pengolahan produk antara menjadi produk akhir.

Gudang yang digunakan untuk penyimpanan produk antara (semi-product) jenis produk 1 dan jenis produk 2 sama, begitu juga dengan gudang penyimpanan produk akhir untuk produk 1 dan 2 . Sistem produksi dua tahap yang diterapkan dalam studi kasus industri pengolahan daging digambarkan pada Gambar 2. 


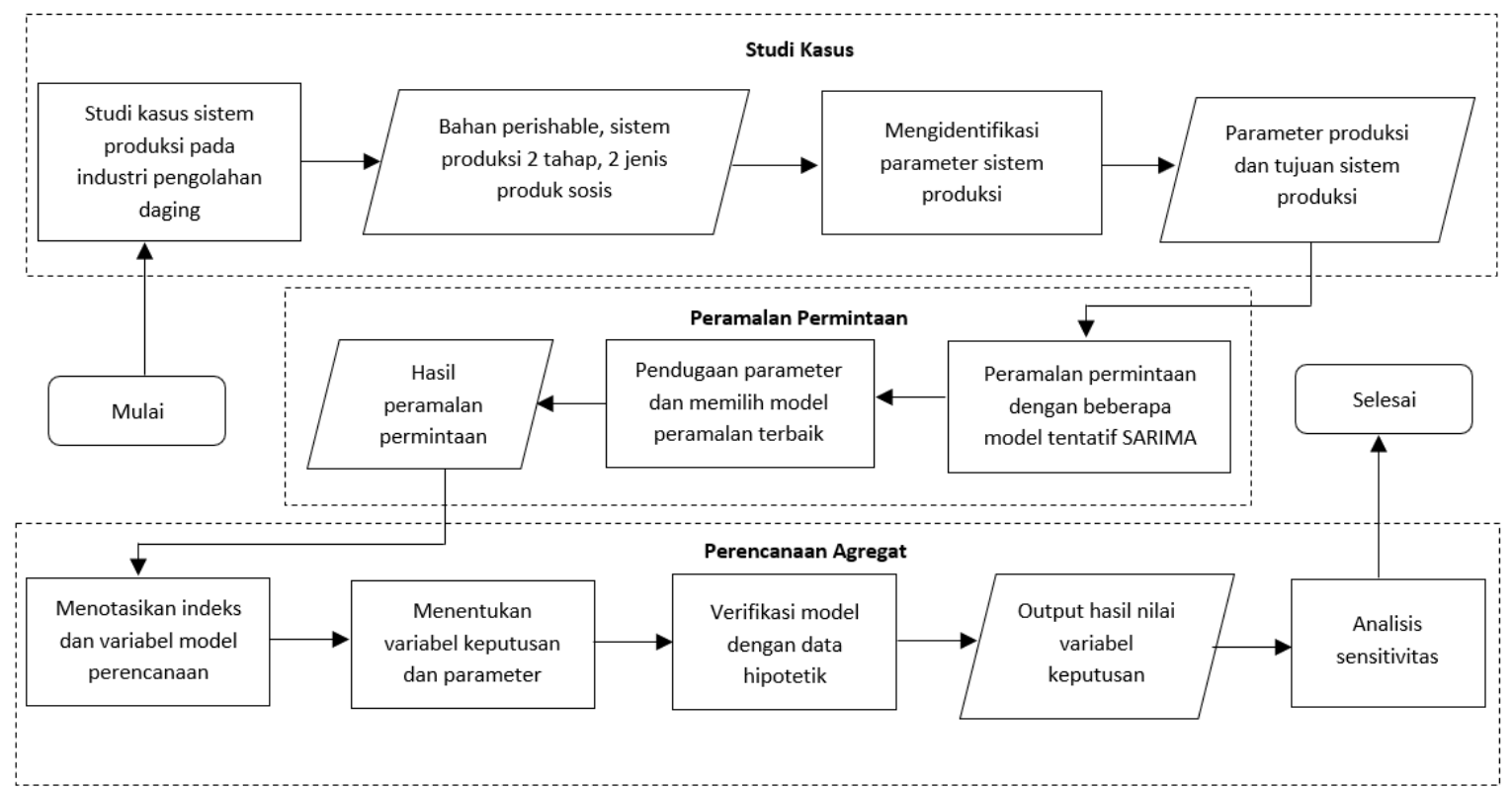

Gambar 1. Kerangka penelitian

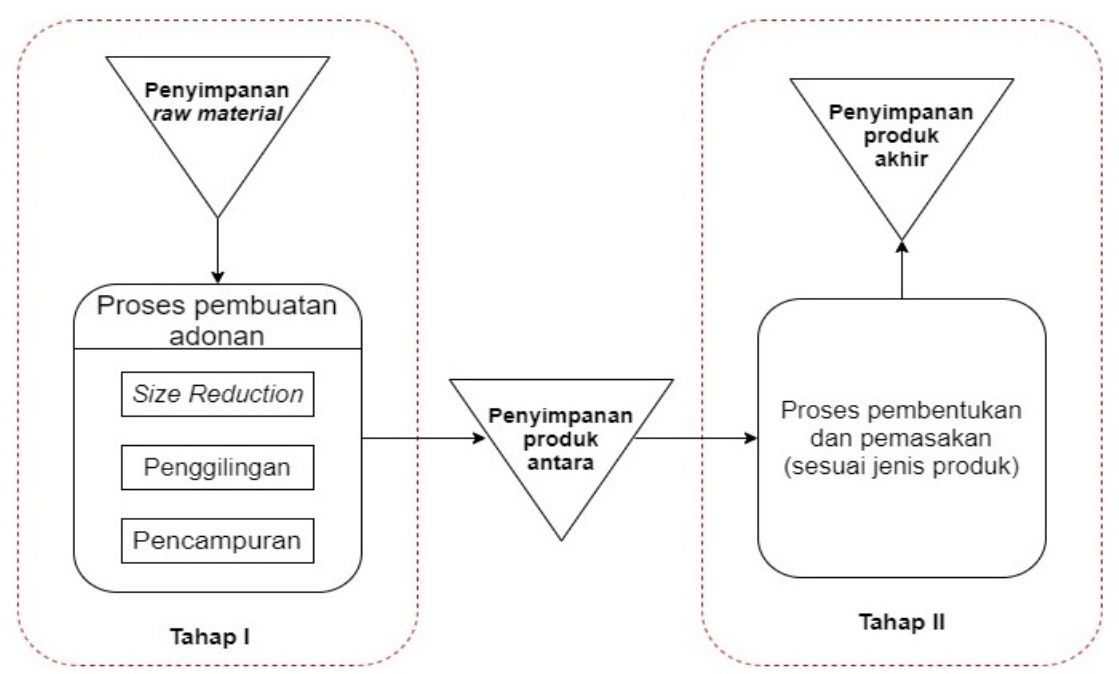

Gambar 2. Sistem produksi dua tahap industri pengolahan daging

Dalam studi ini, model perencanaan agregat untuk sistem produksi dua tahap diharapkan dapat mencapai beberapa tujuan, yaitu:

- Memenuhi permintaan,

- Production cost tidak melebihi anggaran yang ditetapkan,

- Waktu produksi regular tidak melebihi waktu kerja regular yang ditetapkan, dan

- Waktu produksi lembur tidak melebihi waktu kerja lembur yang ditetapkan.

Untuk mencapai beberapa tujuan tersebut, model perencanaan agregat yang diusulkan diselesaikan dengan teknik GP.

\section{Data}

Data yang digunakan pada studi ini merupakan data hipotetik. Data berupa data penjualan masingmasing produk dan data-data parameter model perencanaan agregat. Data yang menjadi parameter model perencanaan agregat merupakan parameter yang terdapat dalam sistem produksi seperti jumlah permintaan, biaya produksi, waktu proses produksi, waktu yang tersedia untuk produksi, kebutuhan ruang penyimpanan, kapasitas ruang penyimpanan, serta yield pada setiap tahap proses produksi, sehingga dapat digunakan untuk melakukan verifikasi pada model.

\section{Seasonal Autoregressive Integrated Moving Average (SARIMA) Model}

Autoregressive Moving Average (ARMA) merupakan model yang umum digunakan dalam peramalan yang melibatkan elemen proses autoregressive (AR) dan moving average (MA) (Forte, 2015). Pada model AR, nilai pada periode $t$ didefinisikan sebagai fungsi dari nilai pada periode $t$ 1 ditambah dengan error-nya, sedangkan model MA menghubungkan nilai $t$ yaitu pada periode saat ini 
dengan kesalahan acak yang terjadi (Ahmad et al., 2013). Model AR dan MA dapat diformulasikan pada persamaan 1 dan persamaan 2:

$\operatorname{AR}(p): Y_{t}=\mu+\beta_{1} Y_{t-1}+\beta_{2} Y_{t-2}+\ldots+\beta_{p} Y_{t-p}+\varepsilon_{t}(1)$

Dengan $Y_{t}$ merupakan nilai pada series, $\beta$ dan $\theta$ merupakan bobot, $\mu$ merupakan rata-rata series, dan $\varepsilon$ adalah kesalahan. Dengan mengintegrasikan model AR dan MA, akan menghasilkan model ARIMA $(\mathrm{p}, \mathrm{q})$ :

$$
\begin{aligned}
& \mathrm{Y}_{\mathrm{t}}=\mu+\beta_{1} \mathrm{Y}_{\mathrm{t}-1}+\beta_{2} \mathrm{Y}_{\mathrm{t}-2}+\ldots+\beta_{\mathrm{p}} \mathrm{Y}_{\mathrm{t}-\mathrm{p}}-\theta_{1} \varepsilon_{\mathrm{t}-1}-\theta_{2} \varepsilon_{\mathrm{t}-2}- \\
& \ldots-\theta_{\mathrm{q}} \varepsilon_{\mathrm{t}-\mathrm{q}}+\varepsilon_{\mathrm{t}}
\end{aligned}
$$

Pada kenyataannya, terdapat banyak deret waktu yang memiliki beberapa bentuk pola tren siklus atau musiman, sehingga model SARIMA digunakan untuk menganalisis pola data tersebut dengan periodisitas. Model SARIMA (p,d,q) $(\mathrm{P}, \mathrm{D}, \mathrm{Q})^{\mathrm{S}}$ merupakan pengembangan dari ARIMA. $d$ menunjukkan berapa kali diferensiasi dilakukan, $p$ menunjukkan komponen AR, dan $q$ menunjukkan komponen MA. Sedangkan $D$ menunjukkan orde diferensiasi musiman dilakukan, $P$ mengindikasikan lag dari autoregression musiman, $Q$ mengindikasikan $\mathrm{MA}$ musiman, dan $S$ menunjukkan panjangnya pola siklus (Liu et al., 2020). Model umum SARIMA sebagai berikut:

$$
\Phi_{\mathrm{p}}(\mathrm{B}) \Phi_{\mathrm{p}}\left(\mathrm{B}^{\mathrm{s}}\right)(1-\mathrm{B})^{\mathrm{d}}\left(1-\mathrm{B}^{\mathrm{s}}\right)^{\mathrm{D}} \mathrm{Y}_{\mathrm{t}}=\theta_{\mathrm{q}}(\mathrm{B}) \theta_{\mathrm{q}}\left(\mathrm{B}^{\mathrm{s}}\right) \varepsilon_{\mathrm{t}}
$$

Menurut Bas et al. (2017), langkah dalam melakukan peramalan menggunakan SARIMA dimulai dari memplotkan data pada grafik periodogram untuk mengidentifikasi pola data. Selanjutnya, data deret waktu didiferensiasi agar menjadi stasioner terhadap varian dimana rataannya dan parameter $d$ dan $D$ dapat diidentifikasi. Diferensiasi tersebut juga dapat mengeliminasi pola tren yang terdeteksi pada plot data. Pola tren tersebut mencirikan fungsi autokorelasi. Selanjutnya, proses tentative ARMA dilakukan berdasarkan estimasi autocorrelation function (ACF) dan estimasi partial autocorrelation function (PACF). Bentuk ACF dan PACF dari deret waktu dibandingkan dengan bentuk model teoritis untuk mengidentifikasi kemungkinan parameter $p, q, P$, dan $Q$. Setelah menentukan model tentatif, parameter model kandidat diestimasi dengan fungsi kemungkinan maksimum. Setelah mencoba beberapa kombinasi parameter, model terbaik dipilih dengan mempertimbangkan error yang dihasilkan. Dalam studi ini, penyelesaian peramalan permintaan dengan model SARIMA akan dibantu menggunakan software Minitab 19.

\section{Model Perencanaan Agregat}

Model perencanaan agregat dibuat dalam model matematika yang akan diselesaikan menggunakan teknik optimasi GP untuk memenuhi keempat tujuan dalam sistem produksi yang telah disebutkan sebelumnya.

1) Notasi

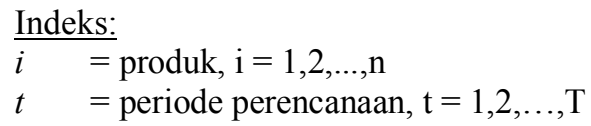

\section{Parameter:}

$D_{i t}=$ permintaan produk i pada periode $\mathrm{t}$ (aspirasi level tujuan 1

$C P_{i}^{d}=$ biaya produksi untuk memproduksi bahan baku i menjadi produk akhir i secara langsung

$C P_{i}^{S}=$ biaya produksi untuk memproduksi bahan baku i menjadi produk antara $\mathrm{i}$

$C P_{i}^{f}=$ biaya produksi untuk memproduksi produk antara i menjadi produk akhir i

$C_{O}=$ biaya produksi yang dianggarkan (aspirasi level tujuan 2)

$t_{i}^{d}=$ waktu proses yang dibutuhkan untuk memproduksi langsung 1 unit (kg) produk akhir i dari bahan baku i

$t_{i}^{S}=$ waktu proses yang dibutuhkan untuk produksi 1 unit (kg) produk i antara dari bahan baku i

$t_{i}^{f}=$ waktu proses yang dibutuhkan untuk produksi 1 unit $(\mathrm{kg})$ produk akhir i dari produk antara i

$M_{t}=$ waktu produksi reguler yang tersedia pada periode $\mathrm{t}$ (aspirasi level tujuan 3)

$\delta=$ fraksi waktu produksi reguler yang tersedia untuk waktu produksi lembur pada peride $\mathrm{t}$

$v_{i}^{S}=$ ruang yang dibutuhkan untuk menyimpan 1 unit $(\mathrm{kg})$ produk antara dari bahan baku

$v_{i}^{F}=$ ruang yang dibutuhkan untuk menyimpan 1 unit $(\mathrm{kg})$ produk akhir dari produk antara

$\overline{\mathrm{I}}_{t}^{S} \quad=\quad$ ruang penyimpanan yang tersedia untuk produk antara dari bahan baku pada periode $t$

$\overline{\mathrm{I}}_{t}^{F} \quad=\quad$ ruang penyimpanan yang tersedia untuk produk akhir dari produk antara pada periode $\mathrm{t}$

$\Upsilon_{i}=$ yield konversi dari produk antara i menjadi produk akhir

\section{Variabel Keputusan:}

$P_{i t}^{d}=$ tingkat produksi produk akhir $\mathrm{i}$ dari bahan baku i secara langsung pada periode $t$

$P_{i t}^{S} \quad=$ tingkat produksi produk antara $\mathrm{i}$ dari bahan baku i pada periode $\mathrm{t}$ 
$P_{i t}^{f}=$ tingkat produksi produk akhir $\mathrm{i}$ dari produk antara i pada periode $\mathrm{t}$

$I_{i t}^{S}=$ tingkat inventory produk antara $\mathrm{i}$ dari bahan baku i pada periode $\mathrm{t}$

$I_{i t}^{F} \quad=$ tingkat inventory produk akhir i dari produk antara i pada periode $\mathrm{t}$

$P O_{i t}^{d}=$ tingkat produksi lembur produk akhir i dari bahan baku i secara langsung pada periode $t$

$P O_{i t}^{S}=$ tingkat produksi lembur produk antara i dari bahan baku i pada periode $\mathrm{t}$

$P O_{i t}^{f}=$ tingkat produksi lembur produk akhir i dari produk antara i pada periode $\mathrm{t}$

\section{Variabel Deviasi}

$d_{1 i t}^{-}=$variabel deviasi bawah $D_{i t}$

$d_{1 i t}^{+}=$variabel deviasi atas $D_{i t}$

$d_{2}^{-}=$variabel deviasi bawah $C_{O}$

$d_{3 t}^{-} \quad=$ variabel deviasi bawah $M_{t}$

$d_{3 t}^{+}=$variabel deviasi atas $M_{t}$

$d_{4 t}^{-}=$variabel deviasi bawah $\delta . M_{t}$

$d_{4 t}^{+} \quad=\quad$ variabel deviasi atas $\delta \cdot M_{t}$

\section{Model Matematika}

Kendala tujuan:

- Memenuhi permintaan

$$
P_{i t}^{d}+P_{i t}^{f}+I_{i t-1}^{F}-I_{i t}^{F}+d_{1 i t}^{-}-d_{1 i t}^{+}=D_{i t}
$$

- Production cost tidak melebihi anggaran yang ditetapkan

$$
\begin{aligned}
& \sum_{t=1}^{T} \sum_{i=1}^{n}\left(C P_{i}^{d} \cdot P_{i t}^{d}+C P_{i}^{s} \cdot P_{i t}^{s}+C P_{i}^{f} \cdot P_{i t}^{f}\right)+ \\
& d_{2}^{-}-d_{2}^{+}=C_{O}
\end{aligned}
$$

- Waktu produksi regular tidak melebihi waktu kerja regular yang ditetapkan

$$
\begin{aligned}
& \quad \sum_{i=1}^{n}\left(t_{i}^{d} \cdot P_{i t}^{d}+t_{i}^{s} \cdot P_{i t}^{s}+t_{i}^{f} \cdot P_{i t}^{f}\right)+d_{3 t}^{-}- \\
& d_{3 t}^{+}=M_{t}
\end{aligned}
$$

- Waktu produksi lembur tidak melebihi waktu kerja lembur yang ditetapkan

$d_{3 t}^{+}+d_{4 t}^{-}-d_{4 t}^{+}=\delta . M_{t} ; \delta=0,5$

Fungsi tujuan:

$$
\operatorname{Min} Z=d_{1 i t}^{-}+d_{2}^{+}+d_{3 t}^{+}+d_{4 t}^{+}
$$

Kendala fungsional:

- Produksi lembur

$$
\sum_{i=1}^{n}\left(t_{i}^{d} \cdot P O_{i t}^{d}+t_{i}^{s} \cdot P O_{i t}^{s}+t_{i}^{f} \cdot P O_{i t}^{f}\right)=d_{3 t}^{+}(10)
$$

- Kapasitas gudang

$\sum_{i=1}^{n}\left(v_{i}^{S} \cdot I_{i t}^{S}\right)=\overline{\mathrm{I}}_{t}^{S}$

$\sum_{i=1}^{n}\left(v_{i}^{F} \cdot I_{i t}^{F}\right)=\overline{\mathrm{I}}_{t}^{F}$

- Yield

$$
I_{i t}^{S}=\left(I_{i t-1}^{S}+P_{i t}^{S}\right)-\left(Y_{i} \cdot P_{i t}^{f}\right)
$$

- Kendala non negative

$$
P_{i t}^{d}, P_{i t}^{S}, P_{i t}^{f}, I_{i t}^{S}, I_{i t}^{F}, P O_{i t}^{d}, P O_{i t}^{s}, P O_{i t}^{f} \geq 0 .
$$

Dalam studi ini, pencarian solusi model perencanaan agregat dibantu dengan menggunakan software LINDO.

\section{HASIL DAN PEMBAHASAN}

\section{Hasil Peramalan Permintaan}

Peramalan permintaan dilakukan untuk masing-masing produk akhir, sehingga terdapat dua hasil peramalan. Data deret waktu penjualan produk 1 dan produk 2 yang digunakan sebagai dasar peramalan permintaan adalah sejumlah 96 periode bulan. Pada langkah pertama, data diplotkan dalam suatu grafik untuk identifikasi pola data secara umum. Gambar 3 menunjukkan plot grafik untuk data deret waktu setiap produk.

Perubahan jumlah penjualan selama periode 8 tahun dapat dilihat pada Gambar 3. Data produk 1 menunjukkan pola yang lebih mudah diidentifikasi dibandingkan dengan produk 2 yang lebih fluktuatif. Pola data produk 1 dan produk 2 menunjukkan pola musiman dengan panjang musim 12 periode, dan terdapat kemungkinan adanya tren.

Selanjutnya, pengujian stasioneritas terhadap ragam dapat dilihat dari Box-Cox plot yang ditunjukkan dengan rounded value $(\lambda)$ dimana dikatakan stasioner terhadap ragam apabila rounded valuenya bernilai 1 . Untuk data penjualan masingmasing produk menunjukkan rounded value bukan 1, maka data tersebut harus ditransformasi terlebih dahulu. Setelah ditransformasi pada masing-masing data hingga rounded value menunjukkan bahwa data stasioner, maka selanjutnya dilakukan pengujian stasioneritas data terhadap rataannya menggunakan grafik ACF dan PACF dari data transformasi. Data dikatakan stasioner terhadap rataannya apabila grafik ACF dan PACF menunjukkan tiga lag pertama masuk dalam ambang batas. Dan berdasarkan plot ACF dan PACF untuk data transformasi produk 1 dan 2, data belum stasioner terhadap rataannya dan perlu dilakukan diferensiasi untuk mengeliminasi pola trend atau musiman. Dengan diferensiasi, pendugaan terhadap parameter $\mathrm{d}$ dan $\mathrm{D}$ juga dapat dilakukan. Untuk melakukan pendugaan parameter $\mathrm{p}, \mathrm{q}, \mathrm{P}, \mathrm{Q}$ dapat didasarkan pada grafik ACF dan PACF dari data hasil diferensiasi. Perlu diketahui bahwa diferensiasi data dapat berupa diferensiasi nonseasonal differencing untuk mengeliminasi tren dan dapat berupa seasonal differencing untuk mengeliminasi musiman.

Grafik ACF dan PACF setelah data dilakukan diferensiasi non-musiman produk 1 dapat dilihat pada Gambar 4, sedangkan grafik ACF dan PACF setelah data dilakukan diferensiasi musiman produk 1 dapat dilihat pada Gambar 5. Selanjutnya dilakukan pemilihan model tentatif dengan mengidentifikasi ordo-ordonya. Berdasarkan grafik tersebut, diperoleh beberapa kandidat model SARIMA $(\mathrm{p}, \mathrm{d}, \mathrm{q})(\mathrm{P}, \mathrm{D}, \mathrm{Q})^{\mathrm{S}}$ di antaranya: $(1,1,2)(1,1,1)^{12} ; \quad(1,1,1)(1,1,1)^{12}$; $(1,1,2)(0,1,1)^{12}$; dan $(1,1,1)(0,1,1)^{12}$. 


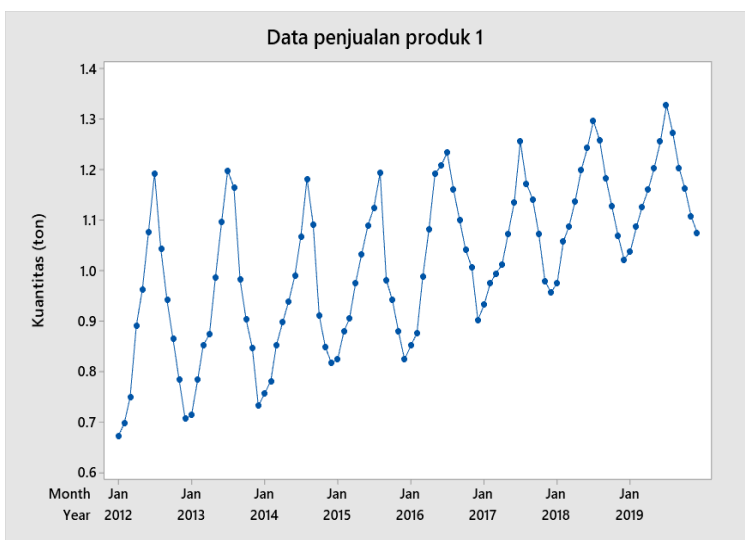

(a)

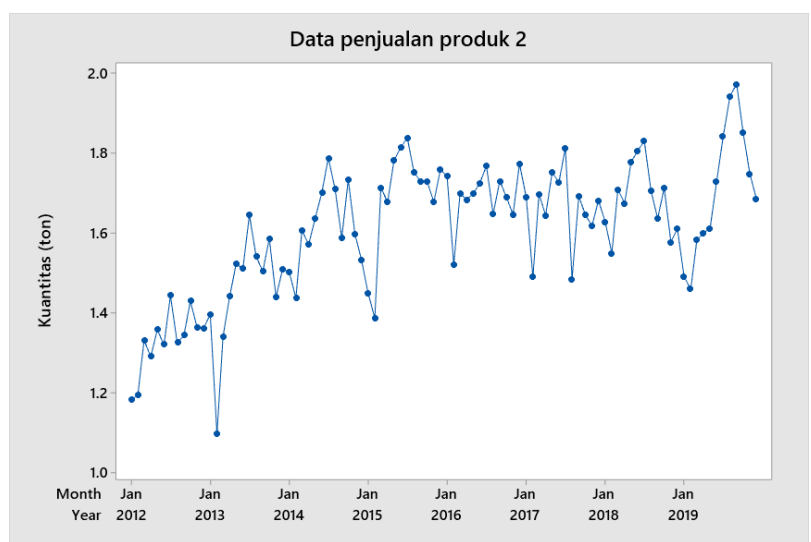

(b)

Gambar 3. Data deret waktu penjualan produk: (a) produk 1, (b) produk 2

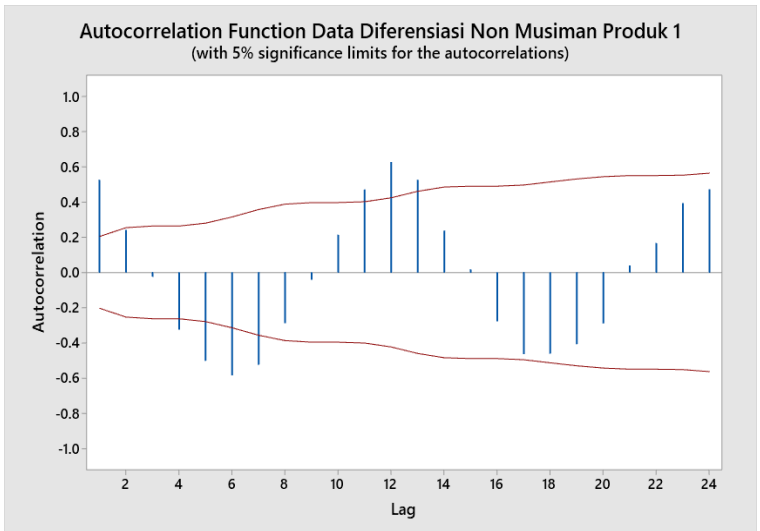

(a)

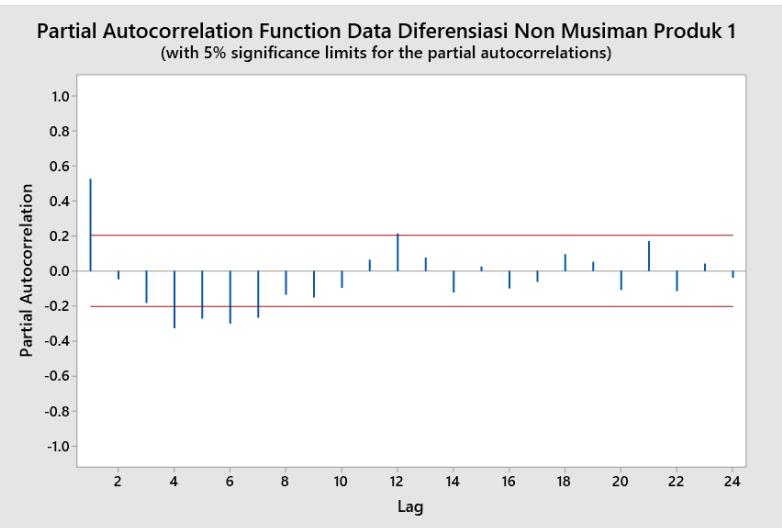

(b)

Gambar 4. Grafik ACF (a) dan PACF (b) data diferensiasi non-musiman produk 1

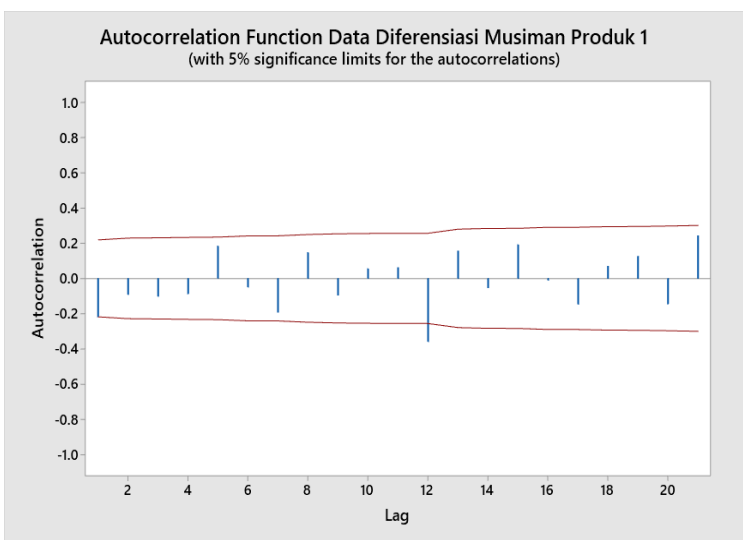

(a)

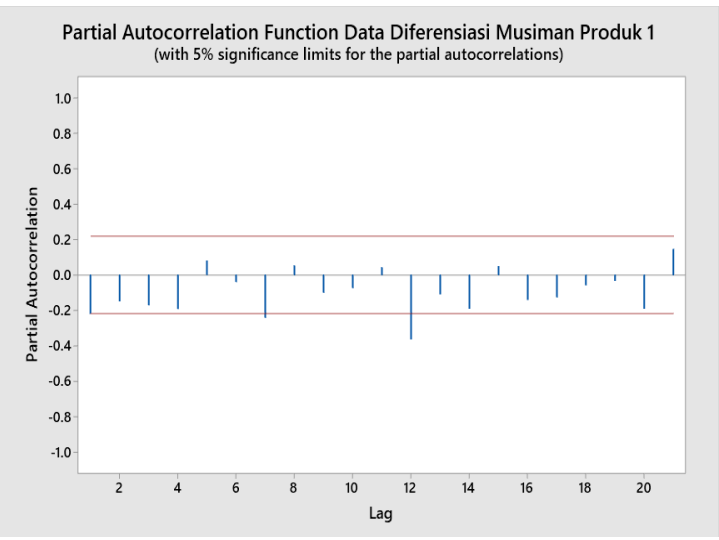

(b)

Gambar 5. Grafik ACF (a) dan PACF (b) data diferensiasi musiman produk 1

Grafik ACF dan PACF setelah diferensiasi untuk produk 2 ditunjukkan pada Gambar 6 dan Gambar 7, sehingga diperoleh beberapa kandidat model SARIMA $(\mathrm{p}, \mathrm{d}, \mathrm{q})(\mathrm{P}, \mathrm{D}, \mathrm{Q})^{\mathrm{S}}$ di antaranya: $(2,1,1)(1,1,1)^{12} ; \quad(2,1,1)(0,1,1)^{12} ; \quad(1,1,1)(1,1,1)^{12}$; $(1,1,1)(0,1,1)^{12} ;(1,0,1)(1,1,1)^{12} ;$ dan $(1,0,1)(0,1,1)^{12}$.
Tahap selanjutnya yaitu dilakukan pendugaan parameter berdasarkan pengujian Ljung-Box dan evaluasi error. Hasil dari pendugaan parameter, pengujian Ljung-Box, dan evaluasi error ditunjukkan pada Tabel 1 untuk produk 1 dan ditunjukkan pada Tabel 2 untuk produk 2. 


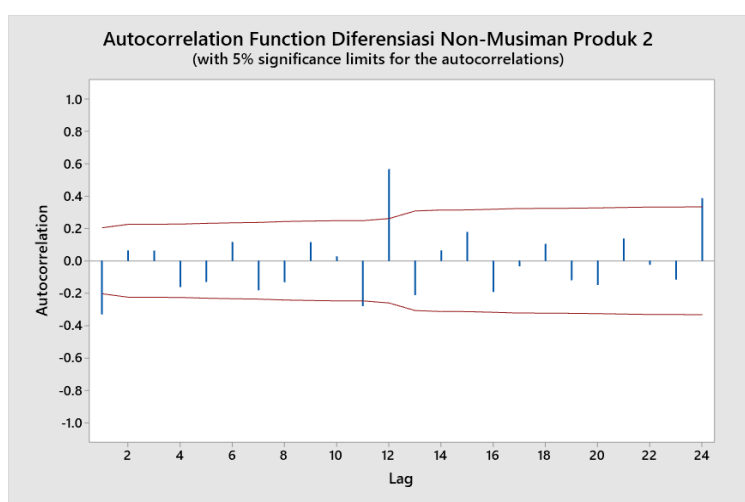

(a)

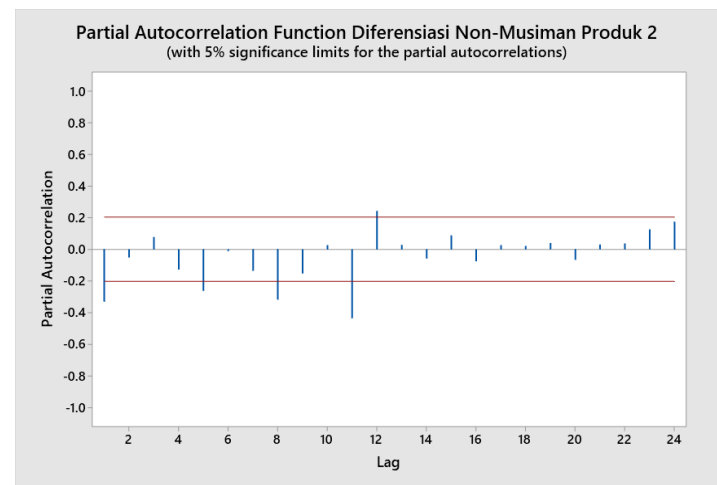

(b)

Gambar 6. Grafik ACF (a) dan PACF (b) data diferensiasi non-musiman produk 2

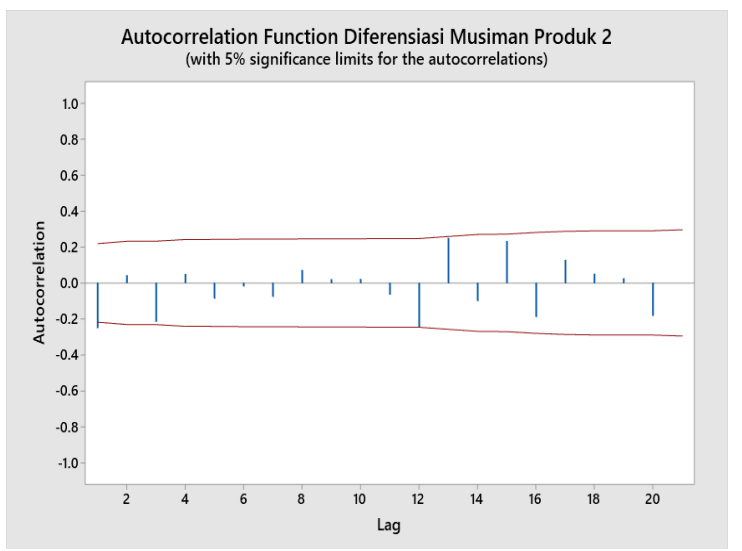

(a)

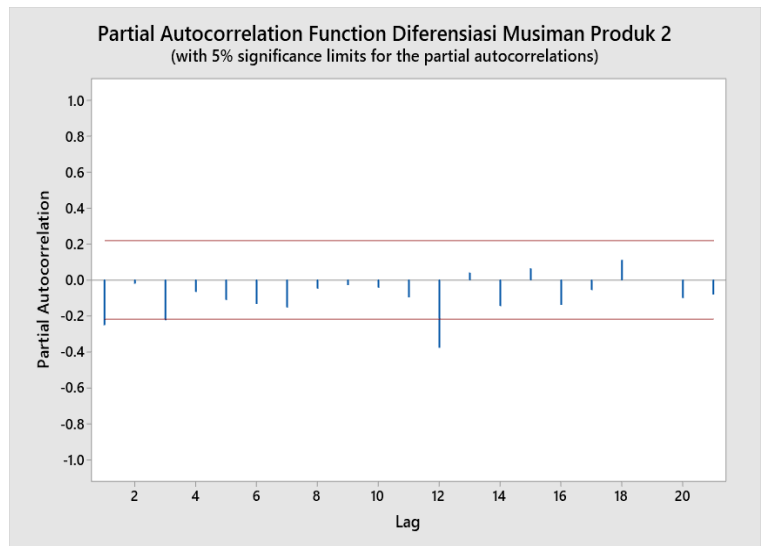

(b)

Gambar 7. Grafik ACF (a) dan PACF (b) data diferensiasi musiman produk 2

Berdasarkan Tabel 1 pendugaan parameter model tentatif, model dikatakan layak apabila $p$-value $<0,05$ dikarenakan tingkat kepercayaan yang digunakan adalah 95\%. Model dengan $p$-value pada setiap parameternya $<0,05$ menandakan bahwa parameter tersebut signifikan dan layak. Model SARIMA $(1,1,1)(0,1,1)^{12}$ untuk produk 1 memiliki $p$ value $<0,05$ pada semua parameternya. Selanjutnya dilakukan diagnosa model untuk mengetahui model yang relevan dengan data, artinya model memenuhi asumsi kebebasan sisaan. Pengecekan dilakukan dengan uji Ljung-Box dengan ketentuan apabila $p$ value $>$ taraf nyata $(\alpha=0,05)$, maka memenuhi kebebasan sisaan. Berdasarkan hasil uji Ljung-Box untuk peramalan produk 1 , diketahui bahwa semua model sudah memenuhi kebebasan sisaan. Pada tahap berikutnya dilakukan evaluasi model berdasarkan tingkat akurasi model yang diukur dari nilai errornya. Software Minitab 19 menunjukkan akurasi model melalui nilai SSE dan MSE. Berdasarkan evaluasi error pada setiap model peramalan produk 1, model SARIMA $(1,1,1)(0,1,1)^{12}$ memiliki SSE dan MSE terkecil, yang artinya model tersebut merupakan model peramalan terbaik. Selain itu, berdasarkan pendugaan parameter dan uji Ljung-Box sebelumnya, model tersebut juga memenuhi kelayakan, sehingga model SARIMA $(1,1,1)(0,1,1)^{12}$ merupakan model terpilih yang akan digunakan untuk melakukan peramalan permintaan produk 1 untuk 3 periode ke depan.

Berdasarkan hasil dari uji Ljung-Box pada Tabel 2, semua model memenuhi asumsi kebebasan sisaan dikarenakan $p$-value untuk semua lag bernilai $>0,05$. Sedangkan berdasarkan hasil pendugaan parameter, hanya model SARIMA $(1,1,1)(0,1,1)^{12}$ untuk produk 2 yang semua parameternya memiliki $p$-value $<0,05$ dan layak. Hal tersebut sejalan dengan hasil dari evaluasi model, dimana model SARIMA $(1,1,1)(0,1,1)^{12}$ memiliki SSE dan MSE terkecil dibandingkan dengan model lainnya. Selanjutnya dilakukan peramalan permintaan produk 2 menggunakan model SARIMA $(1,1,1)(0,1,1)^{12}$

Perlu diketahui bahwa hasil peramalan masih merupakan nilai transformasi, sehingga perlu dilakukan detransformasi kembali. Hasil peramalan permintaan produk menggunakan model SARIMA $(1,1,1)(0,1,1)^{12}$ untuk produk 1 dan produk 2 dapat dilihat pada Tabel 3. Hasil peramalan tersebut merupakan hasil yang sudah didetransformasi seperti data penjualan. 
Tabel 1. Hasil pendugaan parameter, uji ljung-box, dan evaluasi model SARIMA peramalan produk 1

\begin{tabular}{|c|c|c|c|c|c|c|c|c|c|c|c|}
\hline \multirow{3}{*}{ Model } & \multicolumn{5}{|c|}{ P-Value } & \multirow{2}{*}{\multicolumn{4}{|c|}{ Lag }} & \multirow{2}{*}{\multicolumn{2}{|c|}{ Error }} \\
\hline & \multicolumn{3}{|c|}{ Ordo non-musiman } & \multicolumn{2}{|c|}{ Ordo musiman } & & & & & & \\
\hline & $\begin{array}{l}\text { AR } \\
\text { (1) }\end{array}$ & $\begin{array}{c}\text { MA } \\
\text { (1) }\end{array}$ & $\begin{array}{c}\text { MA } \\
(2)\end{array}$ & $\begin{array}{c}\text { SAR } \\
\text { (1) }\end{array}$ & $\begin{array}{c}\text { SMA } \\
\text { (1) }\end{array}$ & 12 & 24 & 36 & 48 & SSE & MSE \\
\hline $\begin{array}{c}(2,1,1) \\
(1,1,1)^{12}\end{array}$ & 0,023 & 0,003 & 0,904 & 0,992 & 0,006 & 0,209 & 0,324 & 0,104 & 0,231 & 0,0092 & 0,000119 \\
\hline $\begin{array}{c}(2,1,1) \\
(0,1,1)^{12}\end{array}$ & 0,000 & 0,000 & - & 0,914 & 0,008 & 0,274 & 0,417 & 0,139 & 0,280 & 0,0090 & 0,000116 \\
\hline $\begin{array}{c}(1,1,1) \\
(1,1,1)^{12}\end{array}$ & 0,018 & 0,003 & 0,816 & - & 0,000 & 0,302 & 0,410 & 0,128 & 0,268 & 0,0092 & 0,000118 \\
\hline $\begin{array}{c}(1,1,1) \\
(0,1,1)^{12}\end{array}$ & 0,000 & 0,000 & - & - & 0,000 & 0,374 & 0,482 & 0,172 & 0,332 & 0,0086 & 0,000109 \\
\hline
\end{tabular}

Tabel 2. Hasil pendugaan parameter, uji ljung-box, dan evaluasi model SARIMA peramalan produk 2

\begin{tabular}{|c|c|c|c|c|c|c|c|c|c|c|c|}
\hline \multirow{3}{*}{ Model } & \multicolumn{5}{|c|}{ P-Value } & \multirow{2}{*}{\multicolumn{4}{|c|}{ Lag }} & \multirow{2}{*}{\multicolumn{2}{|c|}{ Error }} \\
\hline & \multicolumn{3}{|c|}{ Ordo non-musiman } & \multicolumn{2}{|c|}{$\begin{array}{c}\text { Ordo } \\
\text { musiman }\end{array}$} & & & & & & \\
\hline & AR (1) & AR (2) & MA (1) & $\begin{array}{l}\text { SAR } \\
\text { (1) }\end{array}$ & $\begin{array}{l}\text { SMA } \\
\text { (1) }\end{array}$ & 12 & 24 & 36 & 48 & SSE & MSE \\
\hline $\begin{array}{c}(2,1,1) \\
(1,1,1)^{12}\end{array}$ & 0,981 & 0,988 & 0,988 & 0,331 & 0,00 & 0,218 & 0,099 & 0,125 & 0,192 & 4,63 & 0,0601 \\
\hline $\begin{array}{c}(2,1,1) \\
(0,1,1)^{12}\end{array}$ & 0,000 & 0,524 & 0,000 & - & 0,00 & 0,559 & 0,438 & 0,600 & 0,629 & 4,32 & 0,0554 \\
\hline $\begin{array}{c}(1,1,1) \\
(1,1,1)^{12}\end{array}$ & 0,000 & - & 0,000 & 0,956 & 0,00 & 0,615 & 0,447 & 0,567 & 0,560 & 4,21 & 0,0540 \\
\hline $\begin{array}{c}(1,1,1) \\
(0,1,1)^{12}\end{array}$ & 0,000 & - & 0,000 & - & 0,00 & 0,727 & 0,514 & 0,608 & 0,585 & 4,20 & 0,0531 \\
\hline $\begin{array}{c}(1,0,1) \\
(1,1,1)^{12}\end{array}$ & 0,000 & - & 0,143 & 0,396 & 0,00 & 0,641 & 0,484 & 0,536 & 0,521 & 4,29 & 0,0543 \\
\hline $\begin{array}{c}(1,0,1) \\
(0,1,1)^{12}\end{array}$ & 0,000 & - & 0,277 & - & 0,015 & 0,875 & 0,188 & 0,368 & 0,269 & 5,87 & 0,0733 \\
\hline
\end{tabular}

Tabel 3. Hasil peramalan permintaan 3 periode mendatang

\begin{tabular}{ccc}
\hline Periode & \multicolumn{2}{c}{ Hasil Peramalan (kg) } \\
\cline { 2 - 3 } (bulan ke-) & Produk 1 & Produk 2 \\
\hline 97 & 1086,53 & 1629,34 \\
98 & 1139,66 & 1516,05 \\
99 & 1182,76 & 1685,89 \\
\hline
\end{tabular}

Model SARIMA $(1,1,1)(0,1,1)^{12}$ artinya bahwa diferensiasi non-musiman (d) maupun diferensiasi musiman (D) dilakukan masing-masing satu kali, koefisien autoregresi (p) adalah 1, koefisien moving average (q) adalah 1, sedangkan $\mathrm{P}$ yang mengindikasikan lag autoregresi adalah 0 , Q yang merupakan indikator moving average musiman adalah 1, dan terdapat pola siklus musiman (S) yang panjangnya 12 periode.

\section{Hasil Perencanaan Agregat}

Pada bagian ini, data hipotetik yang disesuaikan dengan konidisi sistem produksi, digunakan sebagai parameter model untuk mengetahui fleksibilitas model perencanaan agregat yang diusulkan. Data yang dicobakan pada model, diketahui bahwa diasumsikan terdapat dua jenis produk, $\mathrm{i}=1,2$, dan perencanaan agregat dilakukan untuk periode perencanaan tiga bulan mendatang sesuai dengan hasil peramalan permintaan, $\mathrm{t}=1, \ldots, 3$. Hasil peramalan permintaan yang telah dilakukan digunakan sebagai nilai parameter permintaan yang harus dipenuhi. Parameter lain dalam model di antaranya: biaya produksi, anggaran biaya produksi, waktu proses, waktu produksi regular yang tersedia, waktu produksi lembur yang tersedia, ruang yang dibutuhkan untuk penyimpanan produk, kapasitas gudang, dan yield produksi.

Data hipotetik yang digunakan sebagai parameter model untuk menguji model perencanaan agregat dua tahap dapat dilihat pada Tabel 4 . Parameter $D_{i t}, C_{O}, M_{t}$, dan $\delta . M_{t}$ merupakan right hand side atau aspirasi level yang harus dicapai masing-masing kendala tujuan berdasarkan empat tujuan sistem produksi. Dalam penyelesaian permasalahan multi-tujuan ini, masing-masing tujuan memiliki bobot dan tingkat kepentingan yang dianggap sama, artinya tidak ada tujuan yang lebih diprioritaskan dibandingkan dengan tujuan yang lain.

Dalam GP, untuk memenuhi aspirasi level, terdapat variabel yang disebut variabel deviasi. Variabel deviasi mengindikasikan penyimpanganpenyimpangan yang terjadi untuk mencapai nilai ruas kanan (right hand side) pada kendala tujuan. 
Tabel 4. Nilai parameter model

\begin{tabular}{|c|c|c|c|c|c|c|}
\hline \multirow{2}{*}{ Parameter } & \multicolumn{3}{|c|}{ Produk 1} & \multicolumn{3}{|c|}{ Produk 2} \\
\hline & $\mathbf{t}=\mathbf{1}$ & $\mathbf{t}=\mathbf{2}$ & $t=3$ & $t=1$ & $t=2$ & $\mathbf{t}=\mathbf{3}$ \\
\hline$D_{i t}(\mathrm{~kg})$ & 1087 & 1140 & 1183 & 1629 & 1516 & 1686 \\
\hline$C P_{i}^{d}(\mathrm{Rp})$ & 13000 & 13000 & 13000 & 15500 & 15500 & 15500 \\
\hline$C P_{i}^{S}(\mathrm{Rp})$ & 5000 & 5000 & 5000 & 6000 & 6000 & 6000 \\
\hline$C P_{i}^{f}(\mathrm{Rp})$ & 5500 & 5500 & 5500 & 7500 & 7500 & 7500 \\
\hline$C_{O}(\mathrm{Rp})$ & \multicolumn{6}{|c|}{140000000} \\
\hline$t_{i}^{d}(\mathrm{jam})$ & 0,05 & 0,05 & 0,05 & 0,12 & 0,12 & 0,12 \\
\hline$t_{i}^{s}(\mathrm{jam})$ & 0,04 & 0,04 & 0,04 & 0,08 & 0,08 & 0,08 \\
\hline$t_{i}^{f}(\mathrm{jam})$ & 0,03 & 0,03 & 0,03 & 0,05 & 0,05 & 0,05 \\
\hline$v_{i}^{S}\left(\mathrm{~cm}^{3}\right)$ & 750 & 750 & 750 & 750 & 750 & 750 \\
\hline$v_{i}^{F}\left(\mathrm{~cm}^{3}\right)$ & 540 & 540 & 540 & 720 & 720 & 720 \\
\hline$Y_{i}(\%)$ & 0,9 & 0,9 & 0,9 & 0,88 & 0,88 & 0,88 \\
\hline \multirow{2}{*}{ Parameter } & \multicolumn{2}{|c|}{$t=1$} & \multicolumn{2}{|c|}{$t=2$} & \multicolumn{2}{|c|}{$\mathbf{t}=\mathbf{3}$} \\
\hline & Produk 1 & Produk 2 & Produk 1 & Produk 2 & Produk 1 & Produk 2 \\
\hline$M_{t}(\mathrm{jam})$ & \multicolumn{2}{|c|}{200} & \multicolumn{2}{|c|}{200} & \multicolumn{2}{|c|}{200} \\
\hline$\delta . M_{t}(\mathrm{jam})$ & \multicolumn{2}{|c|}{100} & \multicolumn{2}{|c|}{100} & \multicolumn{2}{|c|}{100} \\
\hline$\overline{\mathrm{I}}_{t}^{S}\left(\mathrm{~cm}^{3}\right)$ & \multicolumn{2}{|c|}{1050000} & \multicolumn{2}{|c|}{1050000} & \multicolumn{2}{|c|}{1050000} \\
\hline$\overline{\mathrm{I}}_{t}^{F}\left(\mathrm{~cm}^{3}\right)$ & \multicolumn{2}{|c|}{2034000} & \multicolumn{2}{|c|}{2034000} & \multicolumn{2}{|c|}{2034000} \\
\hline
\end{tabular}

Misalnya dalam kendala tujuan pertama untuk memenuhi permintaan, variabel deviasi atas menunjukkan suatu kelebihan produksi dibandingkan dengan aspirasi levelnya, dan deviasi bawah menunjukkan suatu kekurangan produksi dibandingkan dengan aspirasi levelnya, dan menggunakan sumber daya yang tersedia.

Kemudian pada kendala tujuan kedua untuk mencapai production cost tidak melebihi biaya yang dianggarkan, variabel deviasi atas menunjukkan kelebihan cost production apabila dibandingkan dengan aspirasi levelnya, dan deviasi bawah mengindikasikan cost production tidak mencapai aspirasi levelnya. Pada kendala tujuan ketiga untuk memenuhi waktu produksi regular sesuai dengan jam kerja regular yang tersedia, deviasi atas merupakan suatu kelebihan waktu produksi regular dibandingkan dengan aspirasi levelnya sehingga akan dialokasikan menjadi waktu produksi lembur, sedangkan deviasi bawah mengindikasikan bahwa waktu kerja regular yang digunakan tidak mencapai aspirasi levelnya atau tidak melebihi waktu produksi regular yang disediakan. Deviasi atas dari waktu produksi regular akan dialokasikan menjadi waktu produksi lembur pada kendala tujuan keempat, dimana deviasi atasnya merupakan waktu kerja lembur yang melebihi aspirasi levelnya dan deviasi bawah merupakan waktu kerja lembur yang tidak melebihi aspirasi levelnya. Berdasarkan penjelasan mengenai variabel deviasi tersebut, dalam GP, fungsi tujuan dirumuskan untuk meminimasi variabel-variabel deviasi yang ada, dengan maksud untuk meminimasi penyimpangan.

Dalam merumuskan fungsi tujuan, perlu memperhatikan variabel deviasi mana yang akan diminimasi. Misalnya dalam kendala tujuan pertama, agar permintaan terpenuhi maka tidak diharapkan terjadi kekurangan produksi, sehingga fungsi tujuan adalah meminimasi variabel deviasi bawah untuk kendala tujuan pertama. Selanjutnya, dalam kendala tujuan kedua, agar production cost tidak melebihi anggaran yang ditetapkan maka tidak diharapkan terjadi kelebihan cost, sehingga fungsi tujuan adalah meminimasi variabel deviasi atas. Begitu juga dengan kendala tujuan ketiga dan keempat, agar waktu produksi regular dan waktu produksi lembur tidak melebihi waktu produksi yang disediakan, maka fungsi tujuan adalah meminimasi deviasi atas untuk kendala tujuan ketiga dan keempat.

Hasil solusi penyelesaian model matematika perencanaan agregat dengan teknik GP dapat dilihat pada Tabel 5 dan Tabel 6. Pencarian solusi GP dibantu menggunakan software LINDO. Berdasarkan hasil yang diperoleh untuk variabel deviasi, ditunjukkan bahwa kendala tujuan pertama tercapai dikarenakan semua variabel deviasi bawah yang diminimasi bernilai 0 . Hal tersebut berarti bahwa tingkat produksi yang dihasilkan berdasarkan sumber daya yang tersedia dapat memenuhi semua permintaan.

Hal serupa terjadi pada kendala tujuan kedua dimana semua variabel deviasi atas yang diharapkan diminimasi juga bernilai 0 . Artinya, cost production tidak melebihi biaya yang dianggarkan, sehingga kendala tujuan kedua tercapai. Namun kendala tujuan ketiga tidak tercapai dikarenakan nilai variabel deviasi atas tidak bernilai 0 , artinya untuk memenuhi kendala tujuan lainnya, waktu produksi regular yang dibutuhkan melebihi waktu produksi regular yang disediakan. Kelebihan waktu produksi regular tersebut akan dijadikan sebagai input waktu produksi lembur pada kendala tujuan 4. Pada kendala tujuan, ditunjukkan bahwa waktu kerja lembur yang dibutuhkan untuk memenuhi target produksi melebihi waktu lembur yang disediakan pada periode perencanaan ke-1, sedangkan pada periode 
perencanaan ke-2 dan ke-3, waktu produksi lembur yang dibutuhkan tidak melebihi waktu produksi lembur yang disediakan atau kendala tujuan ketiga untuk periode perencanaan ke-2 dan ke-3 tersebut tercapai. Dalam kasus tidak tercapainya suatu tujuan sistem produksi seperti ini, solusi yang disarankan yaitu pihak manajerial perusahaan dapat menerapkan sistem rekrut dan pemberhentian tenaga kerja tidak tetap atau menambah waktu produksi lembur yang disediakan.

Hasil dari variabel keputusan yang diperoleh dapat dilihat di Tabel 6. Berdasarkan hasil tersebut, terlihat bahwa tidak selalu produk akan diproduksi secara langsung dari bahan baku menjadi produk akhir, namun ada kemungkinan juga diproduksi dilakukan terlebih dahulu dari bahan baku menjadi produk antara dan baru kemudian dari produk antara diproses menjadi produk akhir. Artinya, model perencanaan agregat dua tahap tersebut dapat digunakan untuk memenuhi berbagai tujuan yang harus dicapai pada sistem produksi. Selain itu, sistem produksi dua tahap juga umum diterapkan pada industri pangan yang memiliki karakteristik bahan perishable. Dengan pemrosesan bahan baku menjadi produk antara, dapat mengatasi laju deteriorasi dari bahan, dan sebaliknya.

\section{Hasil Analisis Sensitivitas}

Dhoruri et al. (2017), melakukan analisis sensitivitas pada model yang diselesaikan dengan GP dengan melihat perubahan koefisien sumber daya/fixed rate pada Right Hand Side (RHS). Analisis sensitivitas diterapkan untuk mengetahui bagaimana pengaruh perubahan parameter model. Perubahan tersebut dapat diimplementasikan pada: koefisien fungsi tujuan, koefisien sumber daya/fixed rate dari kendala sisi kanan atau RHS, koefisien teknis, fungsi kendala tambahan, dan variabel tambahan. Menurut Hadid (2013), analisis sensitifitas diperlukan dalam kelanjutan model, karena dalam kegiatan produksi faktor ketidakpastian itu selau ada. Oleh karena itu, untuk mendapatkan solusi optimal dengan lebih cepat dari masalah yang dihadapi, analisis sensitivitas dibutuhkan (Vanderbei, 2014).

Hasil analisis sensitivitas model dengan melihat perubahan koefisien parameter RHS yang menjadi tujuan sistem produksi dapat dilihat pada Tabel 7. Analisis sensitivitas menunjukkan sejauh mana perubahan nilai RHS agar solusi yang dihasilkan tetap optimal. Apabila perubahan nilai koefisien parameter melebihi allowable increase dan allowable decrease, maka perhitungan harus dilakukan ulang. Misalnya untuk parameter D11 yang merupakan permintaan untuk produk 1 pada periode perencaan 1, nilai parameter RHS adalah $1.087 \mathrm{~kg}$, perubahan kenaikan agar solusi model tetap optimal adalah sebesar 163,13, atau batas atas nilai parameter D11 adalah 1.250,13 kg agar solusi dianggap masih layak. Perubahan penurunan agar solusi tetap optimal adalah 69,24 , atau batas bawah nilai parameter D11 adalah $1.017,76 \mathrm{~kg}$ agar solusi dianggap masih layak. Untuk keseluruhan hasil analisis sensitivitas parameter RHS tersaji pada Tabel 7.

Tabel 5. Hasil variabel deviasi model perencanaan agregat

\begin{tabular}{cccccccc}
\hline Varibel & Nilai & Varibel & \multicolumn{1}{c}{ Nilai } & Varibel & Nilai & Varibel & Nilai \\
\hline$d_{111}^{-}$ & 0 & $d_{112}^{+}$ & 0 & $d_{31}^{-}$ & 0 & $d_{42}^{-}$ & 56,24 \\
$d_{112}^{-}$ & 0 & $d_{113}^{+}$ & 0 & $d_{32}^{-}$ & 0 & $d_{43}^{-}$ & 0 \\
$d_{113}^{-}$ & 0 & $d_{121}^{+}$ & 0 & $d_{33}^{-}$ & 0 & $d_{41}^{+}$ & 194,81 \\
$d_{121}^{-}$ & 0 & $d_{122}^{+}$ & 0 & $d_{31}^{+}$ & 294,81 & $d_{42}^{+}$ & 0 \\
$d_{122}^{-}$ & 0 & $d_{123}^{+}$ & 0 & $d_{32}^{+}$ & 43,75 & $d_{43}^{+}$ & 0 \\
$d_{123}^{-}$ & 0 & $d_{2}^{-}$ & 0 & $d_{33}^{+}$ & 100 & & \\
$d_{111}^{+}$ & 0 & $d_{2}^{+}$ & 0 & $d_{41}^{-}$ & 0 & & \\
\hline
\end{tabular}

Tabel 6. Hasil variabel keputusan perencanaan agregat

\begin{tabular}{crrrrrrr}
\hline Varibel & \multicolumn{1}{c}{ Nilai } & Varibel & Nilai & Varibel & Nilai & Varibel & Nilai \\
\hline$P_{11}^{d}$ & 4853,66 & $P_{12}^{f}$ & 81,27 & $I_{10}^{F}$ & 0 & $P O_{23}^{d}$ & 833,33 \\
$P_{12}^{d}$ & 1058,72 & $P_{13}^{f}$ & 0 & $I_{11}^{F}$ & 3766,67 & $P O_{11}^{s}$ & 0 \\
$P_{13}^{d}$ & 171,05 & $P_{21}^{f}$ & 1629 & $I_{12}^{F}$ & 3766,67 & $P O_{12}^{s}$ & 0 \\
$P_{21}^{d}$ & 0 & $P_{22}^{f}$ & 1516 & $I_{13}^{F}$ & 2754,72 & $P O_{13}^{s}$ & 0 \\
$P_{22}^{d}$ & 0 & $P_{23}^{f}$ & 2444,96 & $I_{20}^{F}$ & 0 & $P O_{21}^{s}$ & 0 \\
$P_{23}^{d}$ & 0 & $I_{10}^{S}$ & 0 & $I_{21}^{F}$ & 0 & $P O_{22}^{s}$ & 0 \\
$P_{11}^{s}$ & 1400 & $I_{11}^{S}$ & 1400 & $I_{22}^{F}$ & 0 & $P O_{23}^{s}$ & 0 \\
$P_{12}^{s}$ & 0 & $I_{12}^{S}$ & 1326,85 & $I_{23}^{F}$ & 758,96 & $P O_{11}^{f}$ & 0 \\
$P_{13}^{s}$ & 73,14 & $I_{13}^{S}$ & 1400 & $P O_{11}^{d}$ & 0 & $P O_{12}^{f}$ & 0 \\
$P_{21}^{s}$ & 1433,52 & $I_{20}^{S}$ & 0 & $P O_{12}^{d}$ & 0 & $P O_{13}^{f}$ & 0 \\
$P_{22}^{S}$ & 1407,23 & $I_{21}^{S}$ & 0 & $P O_{13}^{d}$ & 0 & $P O_{21}^{f}$ & 0 \\
$P_{23}^{S}$ & 2078,42 & $I_{22}^{S}$ & 73,15 & $P O_{21}^{d}$ & 2456,79 & $P O_{22}^{f}$ & 0 \\
$P_{11}^{f}$ & 0 & $I_{23}^{S}$ & 0 & $P O_{22}^{d}$ & 364,6 & $P O_{23}^{f}$ & 0 \\
\hline
\end{tabular}


Analisis sensitivitas dapat mengurangi dan menghindari perhitungan ulang apabila terjadi perubahan nilai parameter model. Selain itu, dengan analisis sensitivitas, dapat diketahui robustness suatu model, dimana robustness mencirikan model yang baik. Jika solusi tidak sensitif atau tahan terhadap perubahan parameter, maka dapat dikatakan model bersifat robust. Hasil analisis sensitivitas yang menunjukkan rentang perubahan nilai parameter mengindikasikan bahwa solusi tahan terhadap perubahan sesuai dengan batas kelayakan solusinya.

\section{KESIMPULAN DAN SARAN}

\section{Kesimpulan}

Paper ini mengusulkan perencanaan agregat dua tahap yang dapat diterapkan pada industri pangan untuk mengatasi karakteristik bahan perishable. Model didasarkan pada studi kasus industri pengolahan daging dengan produk sosis. Peramalan permintaan dilakukan sebagai dasar perencanaan agregrat dengan menggunakan data hipotetik dan metode SARIMA. Proses produksi pada sistem produksi dua tahap terbagi menjadi tiga: 1) pengolahan bahan baku menjadi produk akhir secara langsung, 2) pengolahan bahan baku menjadi produk antara, dan 3) pengolahan produk antara menjadi produk akhir. Sistem produksi dua tahap tersebut mengakibatkan adanya inventory berupa produk antara dan inventory produk jadi. Perencanaan agregat mengakomodasi empat tujuan yaitu: 1) memenuhi permintaan, 2) production cost tidak melebihi anggaran biaya, 3) waktu produksi regular tidak melebihi waktu produksi regular yang disediakan, dan 4) waktu produksi lembur tidak melebihi waktu produksi lembur yang disediakan. Berdasarkan hasil verifikasi model menggunakan data hipotetik yang disesuaikan dengan kondisi sistem produksi dan hasil analisis sensitivitas, model perencanaan agregat yang diusulkan layak diterapkan pada industri pangan dengan sistem produksi multistage (dua tahap), multi-product, multi-periode, serta memiliki karakteristik bahan perishable.

\section{Saran}

Pada penelitian selanjutnya, dapat dilakukan perancangan atau usulan model perencanaan agregat dengan mempertimbangkan adanya faktor penurunan kapasitas mesin dan batasan umur simpan bahan yang disimpan. Selain itu, usulan model selanjutnya juga dapat mempertimbangkan adanya ketidakpastian dalam sistem produksi seperti ketidakpastian permintaan yang dapat diatasi dengan logika fuzzy.

\section{DAFTAR PUSTAKA}

Ahmad WKAW dan Ahmad S. 2013. Arima model and exponential smoothing method: A comparison. Proceedings of the 20th National Symposium on Mathematical Sciences:
Research in Mathematical Sciences: A Catalyst for Creativity and Innovation - AIP Conference Proceedings. April 2013. 1522(1):1312-1321.

Akkerman R, Van Donk DP. 2008. Analysing scheduling in the food-processing industry: structure and tasks. Journal of Cognition, Technology, and Work. 11(3):215-226.

Al-E-Hashem SMJM, Aryanezhad MB, Sadjadi SJ. 2011. An efficient algorithm to solve a multiobjective robust aggregate production planning in an uncertain environment. International Journal of Advanced Manufacturing Technology. 58(5-8):765-782.

Bas MC, Ortiz J, Ballesteros L, Martorell S. 2017. Forecasting 7Be concentrations in surface air using time series analysis. Atmos, Environ. 155:154-161.

Baykasoglu A dan Gocken T. 2010. Multi-objective aggregate production planning with fuzzy parameters. Journal Advances in Engineering Software. 41:1124-1131.

Broz D, Vanzetti N, Corsano G, Montagna JM. 2019. Goal programming application for the decision support in the daily production planning of sawmills. Journal Forest Policy and Economics. 102:29-40.

Chopra S dan Meindl P. 2016. Supply Chain Management: Strategy, Planning, and Operation, $6^{\text {th }}$ ed. Pearson.

Da Silva AN dan Marins FAS. 2014. A fuzzy goal programming model for solving aggregate production-planning problems under uncertainty: a case study in a brazilian sugar mill. Journal Energy Economics. 45:196-204.

Dhoruri A, Lestari D, dan Ratnasari E. 2017. Sensitivity analysis of goal programming model for dietary menu of diabetes mellitus patients. International Journal Modeling and Optimization. 7(1): 549.

Djordjevic I, Petrovic D, dan Stojic G. 2019. A fuzzy linear programming model for aggregated production planning (APP) in the automotive industry. Journal Computers in Industry. 110:48-63.

Forte RM. 2015. Mastering Predictive Analytics with $R, 1^{\text {st }}$ ed. Birmingham: Packt Publishing.

Gansterer M. 2015. Aggregate planning and forecasting in make-to-order production systems. International Journal Production Economics. 170:521-528.

Hadid H. 2013. Pengembangan model penjadwalan penanaman komoditas sayuran greenhouse di pt saung mirwan. [Skripsi]. Bogor: Instutut Pertanian Bogor.

Heizer R dan Render B. 2004. Operation Management. Prentice Hall. New Jersey.

Huang Z, Yu H, Chu X, Peng Z. 2017. A goal programming based model system for 
community energy plan. Energy. 134(1):893901.

Jey HRH, Javanshir H, dan Mohajeri A. 2017. A twostage production planning model for perishable products under uncertainty. Uncertain Supply Chain Management. 5: 201-214.

Leung SCH dan Ng W. 2007. A goal programming model for production planning of perishable products with postponement. Journal Computers \& Industrial Engineering. 53:531541.

Liu H, Li C, Shao Y, Zhang X, Zhai Z, Wang X, Qi X, Wang J, Hao Y, Wu Q, Jiao M. 2020. Forecast of the trend in incidence of acute hemorrhagic conjunctivitis in China from 2011-2019 using the Seasonal Autoregressive Integrated Moving Average (SARIMA) and Exponential Smoothing (ETS) models. Journal Infection and Public Health. 13:287294.

Mehdizadeh E, Niaki STA, dan Hemati M. 2018. A bi-objective aggregate production planning problem with learning effect and machine deterioration: Modeling and solution. Journal Computers and Operations Research. 91:2136.

Mezghani M, Loukil T, dan Aouni B. 2012. Aggregate planning through the imprecise goal programming model: integration of the manager's preferences. International Transactions in Operational Research. 19(4): 581-597.

Pearn WL, Su RH, dan Weng MW. 2011. Optimal production run time for two-stage production systems with imperfect processes and allowable shortages. CEJOR. 19:533-545.

Rad MF dan Shirouyehzad H. 2014. Proposing an aggregate production planning model by goal programming approach, a case study. ISPACS. 2014:1-13.

Ramezanian R, Rahmani D, dan Barzinpour F. 2012. An aggregate production planning model for two phase production systems: Solving with genetic algorithm and tabu search. Journal Expert Systems with Applications. 39:12561263.

Shin M, Lee H, Ryu K, Cho Y, Son YJ. 2019. A twophased perishable inventory model for production planning in a food industry. Journal Computers \& Industrial Engineering. 133:175-185.

Vanderbei RJ. 2014. Linear programming. International Series in Operations Research \& Management Science. 196:99. 